\title{
Differences in biophysical properties of nucleus accumbens medium spiny neurons emerging from inactivation of inward rectifying potassium currents John Steephen* and Rohit Manchanda
}

Address: School of Biosciences and Bioengineering, Indian Institute of Technology Bombay, Mumbai, India

Email: John Steephen* - johneric@iitb.ac.in

* Corresponding author

from Sixteenth Annual Computational Neuroscience Meeting: CNS*2007

Toronto, Canada. 7-12 July 2007

Published: 6 July 2007

BMC Neuroscience 2007, 8(Suppl 2):PI I6 doi:I0.I |86/|47|-2202-8-S2-PI I6

(C) 2007 Steephen and Manchanda; licensee BioMed Central Ltd.

\section{Background}

Nucleus accumbens medium spiny neurons display a two state membrane potential controlled by active channels and synaptic input. Inward rectifying potassium $\left(\mathrm{K}_{\mathrm{IR}}\right)$ channels play a major role in maintaining one of the states, the hyperpolarized down state. The $\mathrm{K}_{\mathrm{IR}}$ currents in $60 \%$ of these neurons are non-inactivating whereas in the remaining, they inactivate [1]. The significance of this difference is unknown. We describe a computational study comparing the biophysical properties of medium spiny neurons possessing these two types of currents.

\section{Methods}

Two medium spiny neuron cells were modeled using NEURON, one equipped with non-inactivating $\mathrm{K}_{\mathrm{IR}}$ currents (henceforth, "Cell $\mathrm{A}^{\text {") }}$ ) and the other with inactivating $\mathrm{K}_{\mathrm{IR}}$ currents (henceforth "Cell B") and their behaviors were compared in response to current injection inputs.
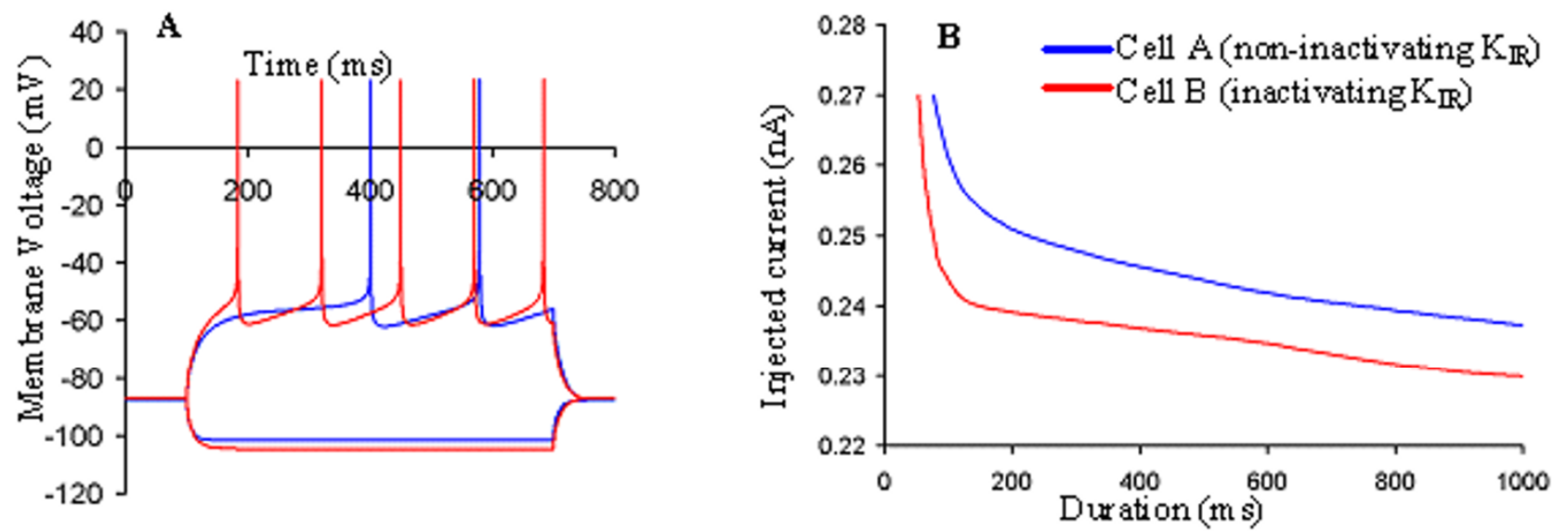

Figure I

Comparison of Cell A with Cell B. (A) Membrane response to injected currents of 0.248 and $-0.2 \mathrm{nA}$. (B) The strengthduration curves of the cells show a significant difference in trend. 


\section{Results}

It was observed that these two kinds of cells were different in several notable ways. For instance, Cell B when compared with Cell A (i) had a resting potential higher by +0.6 $\mathrm{mV}$; (ii) had a higher frequency of firing for the same injected current (Figure 1A); (iii) hyperpolarized more for the same injected negative current (Figure 1A); (iv) reached firing threshold with smaller injected currents; (v) had higher average inter-spike interval (by up to 15\%) with the first spike occurring up to $32 \%$ earlier for injected currents matched for firing frequency; (vi) showed noticeable differences in strength-duration curves (Figure 1B), injected current $v s$ spike frequency curves and voltage-current relationships.

\section{Conclusion}

These results show that clear biophysical differences in the properties of medium spiny neurons can emerge owing to the presence of inactivation in $\mathrm{K}_{\mathrm{IR}}$ channels and indicate that these differences can influence state transitions driven by cortical and hippocampal excitatory inputs. They also suggest that the two types of neurons expressing the different types of $\mathrm{K}_{\mathrm{IR}}$ channels may have computationally different functions.

\section{References}

I. Mermelstein PG, Song W, Tkatch T, Yan Z, Surmeier DJ: Inwardly rectifying potassium (IRK) currents are correlated with IRK subunit expression in rat nucleus accumbens medium spiny neurons. J Neurosci 1998, 18:6650-666I.
Publish with Bio Med Central and every scientist can read your work free of charge

"BioMed Central will be the most significant development for disseminating the results of biomedical research in our lifetime. " Sir Paul Nurse, Cancer Research UK

Your research papers will be:

- available free of charge to the entire biomedical community

- peer reviewed and published immediately upon acceptance

- cited in PubMed and archived on PubMed Central

- yours - you keep the copyright

Submit your manuscript here:

http://www.biomedcentral.com/info/publishing_adv.asp 